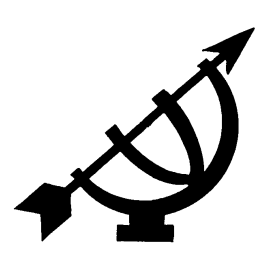

\title{
The uniqueness of cultures, universality and normativity - with special reference to the normative meaning of differentiation ${ }^{1}$
}

\author{
D.F.M. Strauss
}

Faculty of Humanities

University of the Free State

BLOEMFONTEIN

E-mail: fgds@rs.uovs.ac.za

\section{Abstract}

The uniqueness of cultures, universality and normativity - with special reference to the normative meaning of differentiation

The inevitable presence of similarities between different cultures sets a limit to the (irrationalist) claim that the uniqueness of every culture precludes the comparability of cultures. Investigating the background of this untenable view opens up the way to arrive at a reassessment of the role of continuity and universality. This provides the basis of an account of the normative meaning of biotical analogies within the various normative aspects of reality. The characterization of undifferentiated societies in a contrasting way highlights the normative meaning of societal differentiation. Examples of an excessive expansion of the power of particular societal spheres, such as the domain of the church or the scope of science (during the Middle Ages and the modern development of society), demonstrate that the course of factual events frequently does not observe the normative (sphere-sovereign) structural boundaries for differentiated societal collectivities.

\section{Introduction}

Leslie Newbigin once made the observation that it was still fashionable during the 19th century to speak about primitive and civilized cultures. This practice reflects the fact that theorizing during that era was

1 Paper Read at an International Conference of the Association for Calvinistic Philosophy on "Cultures and Christianity A.D. 2000". Bovendonk, Hoeven, The Netherlands, 21-25 August 2000. 
dominated by organic images and metaphors. In particular, the role of Darwinistic evolutionism even caused ideas regarding development to speak about culture in the singular - only with the emergence of cultural relativism it was changed to the plural: cultures (cf. Lemaire, 1976:88 and Griffioen, 1986:84). The 20th century increasingly became critical about this mode of speech. The uniqueness of cultures received more emphasis and at most it was permissible to say that cultures are different. $^{2}$

Does this mean that we have to deny the existence of any norms for cultural development and disclosure? Are there no underlying norms or principles guiding cultural activities and societal structuration? If cultures are uniquely different, does it mean that they lack any similarities? And if there are no similarities between cultures, will it still be possible to speak about culture in general?

Furthermore, in the absence of similarities, are cultures at all related to universal features? If so, what then is the relationship between the universal side and the individual side of cultures?

Once again these questions give rise to other ones. For example, if the underlying universality of the concept of "culture" enables one to apply this term to the most diverse cultures conceivable, is it not then evident that this universality is a lasting feature? In other words, is it possible to conceive of universality without relating it to constancy? Or does this necessarily lead to a static metaphysics of being, as objected to by postmodernism?

It is clear that a serious treatment of these questions can neither sidestep the problem of cultural relativism nor can it avoid the contemporary postmodern attempts to escape from the universality of "reason". But first of all we briefly have to focus our attention on the following question:

\section{What brought universal reason to an impasse? ${ }^{3}$}

During the last number of centuries many more or less related changes emerged on the horizon of the self-understanding of the Western scholarly mind. The glory of an unbridled appreciation of the power and scope of the universalities of human reason did not survive the confines of the age of Enlightenment too well - although the way in which many

2 Most of the time the term "culture" will be employed in a broad sense, practically equivalent to "society" or "civilization." 
portray the long-standing influence of modernity may create that impression.

Soon after the hey-day of 18th century rationalism radically new alternatives emerged. Niebuhr, the tutor of Leopold von Ranke, for example, demonstrates the transition from the 18th to the 19th century in a remarkable way. From the Romantic movement - including Goethe and Schiller (Germany), Bilderdijk and Da Costa (the Netherlands), and Shelley and Keats (Britain) - Niebuhr received his appreciation of mythical thought and that inspired him to make a plea for the wealth enclosed in the historical way of thought.

In opposition to Plato, who accepts only knowledge directed at the true (static) being of things as worthwhile, Niebuhr is convinced that historical change is the true source of knowledge. This kind of knowledge is the most appropriate type of knowledge for the human being as a vital and self-developing entity.

Whereas the 18th century by and large is characterized by the deification of universal (conceptual) knowledge, the rise of historicism highlights an emphasis on the importance of historical change per se. Yet this irrationalist and historicist reaction to Enlightenment rationalism contain hidden problems that became explicit only by the end of the 19th century. It is noteworthy that this process was anticipated by the first critical reactions to Kant's Critique of Pure Reason. It was in particular Jacobi, Hammann and Herder who pointed out that Kant neglected the nature of language in his Critique of Pure Reason. 4

The powerful tradition of natural law which held sway from Grotius up to Kant continued the conviction that there are universally valid principles of law embedded in human reason - such as the rule: pacta sunt servanda (agreements ought to be kept). At the beginning of the 19th century the historical school of law ushered the mentioned new historicist mode of thought into legal science - and as a consequence it considered the following two theses not open to serious objection: (1) positive law as such is a historical phenomenon that cannot deny its link with the past; (2) there is no room for a second system of law (with an eternal and unchangeable content) next to or above the historically developed positive law (cf. Dooyeweerd, 1939:2 ff.). In the opening article of the first

$4 \quad$ That Kant indeed distorted the meaning of history emerged also more clearly during the 19th century - beyond the rise of historicism as such. The discovery of nonEuclidean geometries (by Gauss and Lobatsjevski) relativized Kant's table of categories by making it clear to what extent his analysis of understanding was historically dependent upon Newton's Principia of 1686. 
volume of the Zeitschrift für geschichtliche Rechtswissenschaft (1815) F.C. von Savigny explicitly puts the "historical school" in opposition to the "un-historical school" of rationalistic natural law (cf. Von Savigny, 1948: $14 \mathrm{ff}$.).

The weak point in the conception of natural law is given in its acceptance of a dual validity: in addition to valid positive law it accepts an equally (universally) valid positive law. Although Habermas does not explicitly mention the problem of a duplicated validity entailed in the view of natural law, he does point out that modern "natural law, in preserving the distinction between natural and positive law, assumed a burden of the debt from traditional natural law. It holds on to a duplication of the concept of law that is sociologically implausible and has normatively awkward consequences" (Habermas, 1996:105).

\subsection{Cultural universals or cultural relativism?}

The ultimate effect of the rise of historicism is that it uprooted the idea of normativity. Initially the Baden school of neo-Kantian philosophy (Rickert, Windelband, Weber) postulated next to factual reality a realm of ideal being to which timeless ideas belonged. These ideas were supposed to have an absolute validity since they are not subject to change. Only when factual (natural) reality is related to these timeless values, culture comes into existence (it emerges through Wertbeziehung).

Dilthey, Spengler, Heidegger's irrationalistic reaction to his teacher Husserl, Jaspers and Troeltsch, all contributed in their own way to the general Zeitgeist of the early 20th century in terms of which an appeal to universal principles lost its credibility. The theme of values thus also lost its timeless ideal being since they were now transformed into the domain of (historically changeful) subjectivity: every person has to design (construct) his or her own "values." It should therefore not surprise us that managers involved in mission and vision statements easily nowadays talk about "finding" "new values"!

Because historicism did realize that concept-formation, based upon universal features, is blind with respect to the uniqueness and contingency of historical events, this incongruence finally paved the way for the well-known "turn to language". 5 Already Medieval philosophy taught that the senses have access to individuals - an option once again pursued by

5 Where Gadamer discusses language as horizon of a hermeneutic ontology, he refers to Von Humboldt whose interest in individuality did not lead him away from "the universality of the concept" (Gadamer, 1998:439) - Von Humboldt still wanted to acknowledge the unbreakable correlation between these two features. 
the rise of positivism during the late 19th century (Mach and his followers).

\subsection{Do different cultures "think" differently?}

Prinsloo (1989) approaches this problem from the angle of the relationship between logic and culture. He discusses examples offered by thinkers such as Peter Winch and Evans Pritchard. Whereas these thinkers want to demonstrate that consistency is something different for Westerners and "primitives," he successfully shows that both are actually observing the (underlying, universal, logical) principle of non-contradiction.

The applicability of this principle, however, presupposes the nature of logical concept formation - and concept formation, in turn, rests on the nature of universality. Yet, as we have mentioned, it was exactly this problem - regarding the relationship between universality and individuallity - that haunted the new claims of historicism during the 19th century.

\subsection{The limits of concept formation}

Concept formation inevitably uses universal features. It is indeed blind to what is unique and historically changing. The claim that cultural events are purely unique and individual in nature therefore leads to the mindboggling question of 19th-century historicism: how is it possible to comprehend what is unique and individual if our only access is through concept-formation which is founded upon universal features? This question underscores the classical problem regarding the relationship between universality and individuality. 6

The legacy of restricting knowledge to universality (and therefore to concept formation) is quite old. Having introduced his primary substance Aristotle realized that the purely individual substance cannot be grasped conceptually - inducing him to introduce the secondary substance as the universal substantial form of entities (cf. Metaph., 1035 b 32; De Anima, $412 \mathrm{~b}$ 16). When this house burns down, says Aristotle, then houseness is still intact. The implicit identification of knowledge with conceptual knowledge already present in Aristotle's approach is continued by the adage: omne individuum est ineffabile (cf. De Vleeschauwer, 1952:213). The following statement of De Vleeschauwer illustrates this legacy

6 Cf. the following statement where Habermas highlights this tension explicitly: "How is it possible to grasp the meaning of a unique life context by unavoidably using general categories?" (Habermas, 1970:203). 
sufficiently: "But knowledge of the individual is simply impossible" (De Vleeschauwer, 1952:213).

\subsection{The ultimate source of (cultural) relativism}

The metaphysical "chain of being", the hall-mark of the synthesis between the Greek speculation about eternal forms and the Medieval attempt to accommodate it to the biblical understanding of creation, resulted in the position of realism which assumed a threefold existence of universals: before creation (as ideas in God's mind); inherently within creatures as their universal substantial forms; and subjectively within the human mind as universal concepts. The late-Scholastic nominalism of Duns Scotus and William of Ockham rejected the first two.7 But they did accept universals within the human mind (either as universal concepts or as universal names). Their nominalism therefore in this respect still adheres to the rationalistic trait of realism which identifies conceptual knowledge (on the basis of universal features) with knowledge as such. Paradoxically enough, nominalism at the same time adheres to the basic claim of irrationalism, so clearly elaborated in the stance of modern historicism with regard to changeful historical reality, namely that whatever there is (outside the human mind) is strictly individual. 8

Since language seems to be able to mediate between universality and individuality in a way that transcends the limitations of concept formation, postmodern writers tend to speak about a general shift from concept to meaning, from thought to language. For example, Appleby et al. (1996:1) write: "Using a conceptual shorthand, we could say that meaning has replaced cause as the central focus of attention".

The outcome of the shift from thought to language is significant: the allusivity and equivocal nature of language, particularly well revealed in the role of metaphors, expands and deepens the historicist critique of supposedly universally valid concepts - thus apparently strengthening the relativism already inherent in historicism.

It must be noted, however, that Dilthey and particularly Troeltsch did not want to concede that the liberation achieved through historicism

7 The ambiguous nature of nominalism is treated in more detail in Strauss (1996).

8 Karl Mannheim did grasp something essential of this twofold nature of nominalism: "Nominalism proceeds from the unjustifiable assumption that only the individual subject exists and that meaningful contextures and formations have being only to the extent that individual subjects think them or are somehow oriented toward them in a conscious manner" (Mannheim, 1982:224). 
inevitably ends in relativism. In his dissertation Klapwijk extensively explains this point (cf. Klapwijk, 1970:58 ff., 249 ff.). Yet it was Nietzsche who did see the close link between relativism and the secularization of Christianity. In this regard Hollinger (1994:66) aptly remarks: "Relativism is based on Nietzsche's view that absolute truth is found on 'our longest lie', the belief in God".

Van Riessen points out that Nietzsche increasingly became aware of the opposition in his thought, that between Christ at the Cross and the Nietzschean ideal of the dyonysian, nihilistic Übermensch (Van Riessen, s.a.:101). Nietzsche was at least aware of the fact that the anti-Christ presupposes Christ: "He must have realized that he did nothing else but imitating Christ and reacting against him" (Van Riessen, s.a.:106).

\section{Does the uniqueness of different cultures makes it impossible to compare them?}

Acknowledging cultural diversity and historical uniqueness does not eliminate universality but presupposes it. Only if the phenomenon of culture is something universally human will it be possible to differentiate between the peculiarities of different cultures and to gain an insight into the process of differentiation occurring within societies.

Within a postmodern intellectual climate one may argue that since each culture is unique there are no universal ways in which one talks about them. This mode of thinking currently surfaces in many circles. Van Huyssteen (1998:2-3), for example, holds a similar conviction with respect to the relationship between religion and science: "Postmodernity challenges us to deal with the fact that we have been robbed of any general, universal, or abstract ways to talk about the relationships between religion and science today".

Now suppose that we accept this position for a moment and suppose that we then proceed with an investigation of the legal, the economic and the social practices of different "cultures", against the background of assessing their diverging standards for rationality. Surely, the outcome will be that these differences are real and that many peculiarities will be brought to light. But what is lost sight of in the postmodern frame of mind is the shared and continued presence of the economic, the jural, the social and the rational. If these dimensions of culture and society did not transcend any particular culture and society, recognizing the implied differences would be impossible. Differences only appear on the basis of similiarities, on the foundation of shared properties and features, which in their universality not only transcend any particular "culture", but which make possible the mentioned dimensions of different "cultures". 
Yet, in his rejection of "foundationalism" Van Huyssteen (1999:63) writes:

As will soon become clear, nonfoundationalism, in a strong reaction against modernist and universalist notions of rationality, highlights the fact that every historical context, and every cultural or social group, has its own distinct rationality.

Van Huyssteen apparently does not realize that the differentiated manifestation of the "rational" in different "cultural and social groups" does not negate the universality of rationality, but actually presupposes it! If this statement is not true, why do we still speak about rationality in all the different instances (!) of rationality (!)? What makes it worse is that the statement made by Van Huyssteen entails a universal claim, unmistakenly evidenced in the use of (the universal quantifier) "every": "every (My emphasis - DFMS) historical context, and every (my emphasis - DFMS) cultural or social group."

Similarly, the continued presence of particular legal practices, economic systems and societal collectivities within the most diverse "cultural and social groups" testifies to the same undeniable universal existence of these dimensions in various societies.

The acknowledgement of universal conditions making possible human cultures and societies in the first place does not entail that those acknowledging them had become victims of the rationalistic ("modernist", "foundationalist") fallacy of elevating one's own insight into an unchanging truth. The constancy of what is universal is never identical to any historically and lingually conditioned insight into these conditions.

Moreover, only on the basis of accepting the inevitable presence of (the constancy of) universality is it possible to come to a positive assessment of normativity.

\section{Normativity, changefulness and development}

Given the historicist and hermeneutical challenge to universality, we now have to return to the problem of cultural development. If we want to support Prinsloo (1989) in his reaction against the extreme consequences of historicism with regard to cultural diversity, then we must be able to justify a position which can account for the nature of normativity without abolishing the positive contribution of historicism and the linguistic turn.

- Historicism liberated us from the misplaced rationalistic pride as though it would be possible to arrive at a-temporal truths outside a specific historical context. We can appreciate this insight positively 
without succumbing to the temptation to elevate historical changefulness to an encompassing basic denominator ultimately determining whatever we experience.

- The linguistic turn in addition realized that not only thinking, but also historical circumstances, constantly call for an understanding within a lingual context, i.e. it requires interpretation. But also in this case we have to point out that these two conditions, that of historicity (by the way: a universal) and linguisticality (note: another universal) are just what has been said about them: they are two conditions of being human among many other ones. Admiring them as though they were the only conditions of being human, distorts their own intrinsic meaning, because as soon as we succumb to such a reduction the constancy and universality of these two conditions themselves turn out to be threatened. 9

Assessing cultural development presupposes the contrast between less and more developed, or more extreme, between undeveloped and highly developed. The qualifiers in these two contexts of specification are respectively: (i) more / less, and: (ii) low / high.

It is clear that (i) echoes numerical intuitions, whereas (ii) analogically reflects spatial intuitions. Sometimes sociologists employ the distinction between (iii) "traditional societies" (i.e., societies inclined to perpetuate established societal patterns) and "non-traditional societies" (i.e., societies involved in dynamic processes of social change). In the case of (iii) we note the intuitions of constancy (the kinematic) and change (the physical). Yet the phenomenon of development does not appear in any one of these intuitions. Closer investigation shows that the term development transcends all four of these mentioned modes of explanation (i.e., the numerical, the spatial, the kinematical and the physical). Consequently, we have to consider the contribution offered by the biotic mode of explanation. Development in its original biotic sense entails two correlated and mutually related phenomena: (i) differentiation and (ii)

9 Grondin displays a clear understanding of this impasse with regard to historicism: "Neither the Gadamerian claim to universality - which seems to pertain to language, historicity, and his own philosophy as well - nor its denial by Habermas and Derrida has achieved any final clarity. One might well suppose that 'universality' refers to the universal validity of some proposition. If so, it would be easy to show that hermeneutics is stuck in a logical or pragmatic contradiction. Some have tried to construe the universal claim of hermeneutics as climaxing in the thesis that everything is historically conditioned, a thesis supposed to be universally valid. If this thesis is meant to apply universally, then it must apply to its own claim, which must itself be historically limited and therefore not universal. The universal claim of hermeneutics is thus considered self-contradictory" (Grondin, 1994:10). 
integration. Within the biotic time-order for life - expressed in the cycle of birth, growth, maturation, ageing and dying - every living entity is subject to a biotic process of differentiation. Its counter-part is given in the requirement that such a process of differentiation must remain integrated, for otherwise the process of life will fall apart, i.e., it will disintegrate - a negative effect that may result in a process leading to the opposite of life, namely death.

If it is therefore the case that living entities (plants, animals and human beings according to their function within the biotic aspect of reality) are subject to processes of differentiation and integration, does that then serve as a justification for "extending" these categories in such a way that they also apply to "cultures" and to "human society"?

Various trends of thought during the 19th century - both philosophical and special scientific ones - indeed over-emphasized biotical analogies. This misplaced organicism amounted to an identification of social phenomena with biotical phenomena. As a result human society itself just think about the approach of Herbert Spencer - was seen as a "biotic organism," constituted by different "organs."

During the 20th century many sociologists became highly critical in respect of this legacy. They wanted to move away from the employment of biotical terms altogether. Without making a distinction between "analogy" and "metaphor," Fichter (1968:6 ff.) refers to the "imaginative analogies" used to explain "social life". In a similar vein, but not as totally exclusive, Giddens remarks: "There are few today who, as Durkheim, Spencer and many other in nineteenth-century social thought were prone to do, use direct organic analogies in describing social systems" (Giddens, 1986:163).10

Although Fichter (1968:6) straight-forwardly rejects biologistic, mechanitic, psychologistic and other approaches to sociology, he also does not critically reflect on the use of the expression "social life".

However, as soon as we bring into play the nature of an analogy, which displays the remarkable feature of differences shown within moments of similarities, ${ }^{11}$ then the danger of reduction may be avoided. The mere fact that sociologists from all possible theoretical orientations do not

10 Throughout this work of Giddens we nevertheless repeatedly find the expression "social life" (my italics - DFMS).

11 That is, two things or features are similar in the respect in which they differ and vice versa. 
succeed in suspending the use of the phrase "social life" reveals the inevitability of employing such biotical analogies in sociological theorising.

Of course within the tradition of system theory, which emerged during the first half of the 20th century on the basis of a generalization of the second main law of thermodynamics and Von Bertalanffy's organismic biology, biotic analogies continued to feature in societal theorising. Without showing in any way an awareness of the fact that the term "differentiation," in its original meaning, refers to the biotic aspect of reality, it is therefore more than accidental that Luhmann, who explicitly works within the tradition of system theory, would argue for the inevitability of using this term. Not only does he support his position on the basis of historical research (cf. Luhmann, 1985), since in a systematic sense he also points out that no single trend in sociological theorising succeeded in getting away from its use:

In fact, all of the criticism that has been aimed at this concept and its application in different social theories has been unable to eliminate it completely, no matter how justified the individual arguments may have been. The concept of (social) differentiation simply proved irreplaceable. So the question must be asked: why? (Luhmann, 1990:409).

Unfortunately his subsequent analysis does not systematically account for the differences between biotic development (evolution) and social evolution, for when he enters into a discussion of the phenomenon of social evolution he explicitly states: "At present the concept of evolution is used in the same sense as the one conferred on it by Darwin" (Luhmann, 1990:428). On this basis he interprets "chance" to mean the "absence of system coordination". As a consequence he considers "evolution that begins from any system-state" to be "improbable": "What evolution theory ultimately tries to explain is the becoming probable of what is improbable" (Luhmann, 1990:428).

Luhmann thus becomes a victim of a genetic approach which can no longer account for universal constant structural principles lying at the basis of societal development and in that sense do not fit the opposition of probable and improbable. Furthermore, his first examples simply show that he deviates from the very meaning of biotical analogies in the explanation of societal differentiation, as could be seen from his challenge to "systems theory" which has "to explain how and under what conditions territorial [societies] are transformed into larger units (lineages, clans, villages), and these again into still larger ones (tribes)" (Luhmann, 1990:428). Suddenly the (biotically sensitive) nuanced analysis of the meaning of differentiation gave way to the simple numerical-spatial perspective of smaller and larger. 
His reference to "lineages, clans, and tribes" are to the point if one wants to understand undifferentiated societies, but "villages" are present both in differentiated and undifferentiated societies. Let us proceed with a brief sketch of the undifferentiated nature of the extended family, the clan (sib) and the tribe, for highlighting the contrast between differentiated and undifferentiated societies will enhance an insight into the normative meaning of social differentiation.

\subsection{Societies in an undifferentiated condition}

The first general characteristic which can be pointed out is given in the indication which we have chosen: its being undifferentiated. This undifferentiated feature marks both its foundation and its qualification. Natural things, for example, are characterized by a unique base-function (called their foundational function) and their distinctness ultimately depends on that aspect of reality which guides the structural unity of their functioning - it is called their qualifying function. The formula $\mathrm{C}_{3} \mathrm{H}_{6} \mathrm{O}$ may yield the following (chemically distinct) structures: $\mathrm{CH}_{3} \mathrm{CH}_{2} \mathrm{CHO}$ or $\mathrm{CH}_{3} \mathrm{COCH}_{3}$. The same applies to $\mathrm{C}_{4} \mathrm{H}_{4} \mathrm{O}_{4}$ where a different spatial organization results in two different kinds of acid (Maleic acid and Fumaric acid). In other words, molecules such as these have their foundational function in the spatial aspect and they are qualified by the physical aspect. Plants are qualified by the biotic aspect and animals by the sensitive mode (the biologist, Adolf Portmann [1969:86], says that animals are instinctively secured and bound to a specific milieu).

In an undifferentiated society such univocal radical-typical functions as are found in nature are absent. 12 All activities in such a society are bound together in one undifferentiated organizational form. In a differentiated society, by contrast, each distinct social form of life possesses its own form of organization, which coheres with the fact that each societal life-form as such is univocally characterized by its own differentiated qualifying function.

Kammler suggests that the term "natural people" be avoided owing to the idyllic connotation attached to it by Rousseau. According to his understanding of the discipline of ethnology [cultural anthropology] and sociology, human societies are called "primitive" (we would prefer to say: undifferentiated) when they meet the following two requirements:

- if its technology is still largely undeveloped and accordingly its productivity is relatively insignificant; and 
- if it harbours a low degree of socio-cultural differentiation - in other words, the realization of political and administrative, economic, juridical, cultic religious and educational functions initially bound together in the family bond are still absent or they are at least only present in a rudimentary form.

The counter-part of "undifferentiated" societies is then designated as "complex societies" (Kammler, 1966:17-18).

Since undifferentiated societies are encapsulated in an undifferentiated organizational form, the possibility of differentiated qualifying functions is precluded. The diversity of societal life-forms which, in the course of a gradual process or cultural-historical differentiation (and disclosure) ${ }^{\mathbf{1 3}}$ come to the fore, are bound together in an undifferentiated manner within such a society. That is why such a society does not only exhibit an economic aspect, because the whole acts as something which is recognised on a differentiated cultural level as an economically qualified societal collectivity - such as the firm. In cases like these an undifferentiated society partially manifests itself in the form of an economic enterprise such as a hunting, agricultural or cattle farming type. Similarly, an undifferentiated society does not merely exhibit a jural aspect, because as a whole it acts in the fulfilment of the functions which, on a differentiated level of societal development, are performed by an independent state. The same applies to the faith aspect - the undifferentiated society acts as a whole in a cultic-religious capacity, similar to a collective faith community in a differentiated society. Within the total organizational form of an undifferentiated society we therefore find a diversity of structurally typical "evaginations", which time and again brings its totality to those activities which are performed by independent life-forms within differentiated societies.

This state of affairs implies that the correlate of an undifferentiated foundation (viz. one total organizational form) is given in an undifferentiated qualification. It means that there can be no possibility of a univocal qualifying function, because one of the interlaced structures performs the leading role. This is obvious from the nature of the most basic type of undifferentiated societies. This type of society, which binds parents, children and grandchildren together in a patriarchal unit, puts the patriarch and the oldest son in such a position that it cannot be ex-

13 Disclosure here refers to the opening up of the anticipatory analogical moments within the modal aspects of reality. However, in the present context we will not enter into a discussion of the process of disclosure. 
clusively derived from the blood relationship which exists between them - for that a specific kind of historical organization of power is required.

The extended family does not only evince a family structure, because in its undifferentiated total structure other life-forms are also interwoven. The presence of the political structure is clear from the (political) force with which the patriarch maintains internal order and peace. With equal clarity the economic enterprise can be distinguished through the way in which the subsistence economy functions. The question is: which one of the interlaced structures takes the lead in the undifferentiated total structure?

The role which the (fatherhood-related) family structure plays in the extended family is truly of a central leading nature - despite the fact that the interwoven family structure itself does not inherently possess a permanent structure of super- and sub-ordination.

The sib (clan or gentes), which apparently only occurs when agriculture and livestock farming partly or completely replaces hunting as the basis of economic life, is a larger group of relations (where either only the father's or the mother's line of descent is taken into account) which is organized in a coordinated way. Normally, membership is dependent on blood relationship, that is to say, it rests on natural birth. However, the sib is so large that it is no longer possible (as in the extended family) to assume direct descent from a communal father - although such descent functions as a fictitious presupposition or mythological conception. Besides activities like the ancestor cult (typical of an eventually differenttiated cultic institution), carrying out revenge (which within a more differentiated context, is carried out by an independent state with its judiciary system and penal law-sphere), and like the presence of forms of division of labour, also the family structure finds its place within the total structure of the sib. In reality this interwoven family takes on the role of the undifferentiated leading structure within the sib - a leading role which rests on a particular historical form of power organization (just as in the case of the extended family).

It is only the stronger organized tribe that displays such a prominent political organization that the interwoven family structure cannot any longer take the lead in it. Nonetheless, there is not yet any mention of an enduring monopolistic organization of the sword power in this leading political structure (as in the case of a true state), because even fights between members of the same tribe do not provoke any tribal punishment - only a relative of someone who is killed in such a fight could consider revenge. 


\section{Differentiation and integration as norms for societal development}

If it is the case that one cannot escape from the acknowledgement of biotical analogies in an analysis of aspects such as the social, the economical or the jural then one has to combine this perspective with the obvious normative nature of the post-sensitive (psychical) aspects of reality. This integrated perspective highlights the insight that every modal analogy within the structure of any normative aspect (from the analytical up to and including the faith aspect), articulates a fundamental modal norm within the aspect concerned. On the basis of the biotic analogy within the structure of the social aspect one may discern the (modalaspectual) norms of social differentiation and social integration.

In respect of the biotic analogy within the economic aspect, Hart (1984: 158) asks significant questions:

What about growing economies? ... The newspapers are sure that economies grow, whether slowly, quickly, or hardly at all. Is such talk meant literally? Growing grass makes sense. Is growing in an economic sense anything more than a metaphor? Do we feed or fertilize an economy? Do we give it water, or protect it from too much sun? Do we just have a peculiar use of language here, or does the language point to something more basic?

Within every normative aspect of reality every (retrocipatory or anticipatory) analogical moment actually constitutes a fundamental modal norm within the aspect concerned. Therefore every biotical analogy at the norm-side of any normative aspect represents a fundamental modal principle for human action.

The original meaning of the biotic aspect, as we have seen, comes to expression in phenomena designated by terms such as life, growth, adaptation, differentiation, integration, finality (goal-directedness/Planmässigkeit), and so on. Acknowledging the analogy between biotic development, proceeding from an undifferentiated condition to a more differentiated level in itself is not the outcome of a (neo-Darwinistic) evolutionistic interpretation. Griffioen (1986:84 ff.) is not sufficiently articulated in this regard. Yet his critical comments in respect of Dooyeweerd's analysis of primitive cultures are to the point (Griffioen, 1986:89-94). Dooyeweerd did not sufficiently account for the truly normative dimension present in all cultures - even those who are "thrown back" to sub-human realities under the guidance of apostate faith - and he also did not effectively apply the structure/direction distinction at the level of undifferentiated societies: next to apostate undifferentiated 
societies there are also undifferentiated ones developing under the guidance of biblical faith (such as those recorded in the Old Testament).

Unfortunately Griffioen nowhere in his illuminating and penetrating article explicitly undertakes the task of "locating" the "modal seat" of the term differentiation (and its correlate: integration) - which is to be found in the biotic mode of reality. In addition he also does not explicitly account for the fact that the inter-modal coherence between the normative aspects and their foundational connection with the biotical (and other natural) mode(s) actually highlights fundamental modal norms requiring positivization of the process of cultural development.

The normative meaning of the principle of societal differentiation entails that a partial differentiation may lead to an imbalance and disharmony in the development of society. This was the case during the Middle Ages during which the Roman Catholic church emerged as a quasi-differentiated "super-structure" which excessively expanded its ecclesiastical power over the rest of Medieval society that continued the undifferentiated legacy of the Roman familia and the Germanic household community. Both of these communities assigned absolute and totalitarian power to those who occupied the office of head. The chief of the Germanic household community had personal dominion over those belonging to him. The feudal era continued this undifferentiated "substructure" of Medieval society, which made it possible for the Roman Catholic church to establish an ecclesiastically unified culture during the later Middle Ages.

After the disintegration of the Carolingian empire - which acquired its peak during the ninth century A.D. - it eventually only was the Roman church that managed to act as an integrating force in Medieval society. The continued Roman Catholic church domination reached its zenith during the first two decades of the 13th century under Pope Innocent III. According to the doctrine of the "two swords" the Pope had to handle the spiritual sword and the government the earthly sword.

The strange reference of Christ (Luke 22:38 ff.) to those who do not have a sword and should sell their clothes and buy one, is interpreted by the early church that the words of Christ, "It is enough", mean that the two swords will be sufficient. However, the church fathers rejected the idea of two swords with an appeal to Matthew 26:52: "Put your sword back in its place ... for all who draw the sword will die by the sword". Apparently in opposition to this Christ claims that he "did not come to bring peace but a sword" (Matt. 10:34). 
In the fourth century A.D. Ambrose of Mailand interpreted this statement in the sense of Ephesians 6:17 - it refers to the sword of the spirit, which is the Word of God. Even in the twelfth century Anselm of Laon still interpreted the two swords of Luke as the Word of God - in the Old and the New Testament (cf. Borst, 1966:34).

Frederik I Barbarossa (1152-1190), who claimed among others in 1158 (cf. Stüttler, 1969:32), that the imperial highness is independent from the church, did that on the basis of the particular appreciation of the imperial mission which evinces, via Charles the Great, continuity with the antique Roman emperors.

In a circular from the year 1157 he emphasizes that this authority is independent and only accountable to God. He argues that Christ acknowledged it in terms of the theory of two swords:

Considering that the Divine power, from which all other power in Heaven and on earth is derived, has committed to us, whom it had anointed, the kingdom and the Empire to rule over ... And as the kingdom and the Empire belong to us, being granted to us through the election of the princes by God alone, Who has subjected the world in the passion of His Son Christ to the rule of the two swords, and since the Apostle Peter has enlightened the world with his teaching, 'Fear God, honour the king', whoever may say that we have obtained the Imperial Crown as a benefice from the lord Pope, contradicts the Divine institution and the teaching of Peter and shall be guilty of a lie (Ehler \& Morrall, 1954:61-62).

This attempt to divorce the authority of the emperor from the church increasingly experienced opposition. During the era of Pope Innocent III at the beginning of the thirteenth century it was clear that the papal power reached its climax. The exceptional personality and stature of this Pope certainly contributed to it. He was an outstanding theologian and jurist with unique leadership features. In his letter Sicut universitatis he articulates his view on the relation between the "spiritual" and the "temporal sword" by employing the image of the sun and the moon:

Just as God, founder of the universe, has constituted two large luminaries in the firmament of Heaven, a major one to dominate the day and a minor one to dominate the night, so he has established in the firmament of the Universal Church, which is signified by the name of Heaven, two great dignities, a major one to precide - so to speak - over the days of the souls, and a minor one to preside over the nights of the bodies ... Both these powers or leadership have their seat established in Italy, which country consequently obtained the precedence over all provinces by Divine disposition (Ehler \& Morrall, 1954:73). 
Note that both "powers" are now conceived of within the space of the "universal church". Soon this conception would resound within the "earthly power", for in 1232 Emperor Frederik II wrote in a letter to Pope Gregory IX that the clergy and the emperorship are only separated in respect of the word designating them - in their operation they are united: "In truth there exist two swords, but one and the same mother church, the generator of our faith, is the sheath for both" (Borst, 1966:41).

The prelude to the formulation of the famous papal writing Unam Sanctam (1302) demonstrates the on-going struggle between the spheres of competence of these two "powers". Kates (1928:8) remarks: "The opening of the fourteenth century saw the duel between Boniface VII and Philip the Fair; between John II and Louis of Bavaria, or rather his spokesman, Marsilius of Padua".

Pope Boneface VIII reacted to the fact that King Philip of France taxed the French clergy without an antecedent agreement with Rome. According to him this act violates the freedom of the church from "worldly" control. From the perspective of the emperor it demonstrates the fact that the "worldly power" continues to find it unacceptable to be subjected to the Pope with regard to secular affairs. However, Bonaface unites the theory of the "two swords" in a manner which ascribed more power to the church, since, according to him, God - as the Origin of all spiritual and temporal power - gave both swords to the church:

If therefore, the earthly power err, it shall be judged by the spiritual power; if the lesser spiritual power err, it shall be judged by the higher, competent spiritual power; but if the supreme spiritual power err, it could be judged solely by God, not by man (Ehler \& Morrall, 1954:92).

Not only does Bonaface proclaim with this a decisive power of the church regarding all "earthly" matters, since he even holds the conviction that outside the Roman papacy no salvation could be acquired: "Consequently we declare, state, define and pronounce that it is altogether necessary to salvation for every human creature to be subject to the Roman Pontiff" (Ehler \& Morrall, 1954:92).

However, during the rise of the Renaissance, this one-sidedness in the semi-differentiated structure of Medieval society was challenged by an opposing trend, known as late Scholastic nominalism. This reaction eventually gave birth to the rise of modern humanism which soon, in spite of the Protestant Reformation of the 16th century, took over the leading role in the development of Western culture.

But having broken through the unifying power of the Roman Catholic church the new era first witnessed the opening up of new possibilities of 
differentiation, such as the differentiation between state and church in the era in which the nation states started to emerge, the liberation of a differentiated economic sphere (eventually completed in the differentiation of the nuclear family and the modern firm (during the Industrial Revolution), and, since the rise of the first universities in France and England, the eventual autonomy of scholarly reflection as a differentiated power alongside the other differentiated spheres of the developing Western society.

This process of differentiation did not develop in a norm-conformative way, since excessive tendencies within the newly differentiating spheres of society continued to threaten others, causing a marked disharmony in this process of societal development. During the 18th century, for example, natural science enthroned by the glorification of human reason wanted to subdue institutions for justice and religious convictions to its own standards of rationality - just compare the characteristic phrase in the Foreword to the first edition of Kant's Critique of Pure Reason (1781):

Our age is, in every sense of the word, the age of criticism, and everything must submit to it. Religion, on the strength of its sanctity, and law, on the strength of its majesty, try to withdraw themselves from it; but by so doing they arouse just suspicions, and cannot claim that sincere respect which reason pays to those only who have been able to stand its free and open examination (Kant, 1956 [1781]:A-xi).

Similarly, the guidance of the classical liberal idea of the state - with its motto of laissez faire, laissez passe - misleads governments to neglect their task of integrating the multiplicity of legal interests within their territories into one public legal order. The effect was that the new capitalist generation of ownership, which emanated from the new possibilities created by the Industrial Revolution, was allowed to exploit "labour" to such an extent that socialist and eventually communist ideas found their way to practical politics - in the final analysis subjecting Western societies to an on-going class struggle. Among other things it gave birth to the three destructive totalitarian regimes of the 20th century (communism, fascism and national socialism), which once again demonstrate the catastrophic consequences of a process of development guided by an apostate ideology not observing the inner structural limits set to the power-sphere of differentiated societal institutions boundaries aptly captured by a phrase already introduced by Groen van Prinsterer in the 19th century and elaborated by Kuyper and Dooyeweerd during the later 19th century and the 20th century: sphere-sovereignty.

\section{Concluding remark}

An alternative formulation for this article could have read: 
Does Cultural Diversity entail relativism and therefore contradicts the norm of Societal Differentiation?

In summarizing the argumentation advanced we may in conclusion phrase it as follows:

- The enduring shared properties between different cultures testify to the presence of universality and constancy lying at the basis of all the unique peculiarities evinced by different cultures.

- Only the acknowledgement of the foundational role of universality and constancy with respect to change and development opens up an alternative approach.

- The aim of an alternative approach is to arrive at a constructive understanding of the normative meaning of biotic analogies within the normative aspects of reality.

- The interconnectedness between different aspects of reality opens up the view that the natural aspects represent normative analogies within the normative aspects of reality - designated as modal principles.

- Consequently, the biotic analogy within the social aspect is manifested in the normative principle of social differentiation.

- Distortions and instances of antinormativity in the process of giving form (in the positivisation) of this principle does not cancel its overarching and guiding role in societal development.

\section{Bibliography}

APPLEBY, J. 1996. Knowledge and Postmodernism in Historical Perspective. Edited by Joyce Appleby, Elizabeth Covington, David Hoyt, Michael Latham, Allison Sneider. New York \& London : Routledge.

BORST, A. 1966. Der mittelalterliche Streit um das weltliche und das geistliche Schwert (Hrsg. W.P. Fuchs). (In Fuchs, W.P. Staat und Kirche im Wandel der Jahrhunderte. Mainz : s.n. p. 34-52.)

DE VLEESCHAUWER, H.J. 1952. Handleiding by die studie van die Logika en die Kennisleer. Pretoria : Moerau.

DOOYEWEERD, H. 1939. Recht en Historie. Assen : Van Gorcum.

DOOYEWEERD, H. 1997. A New Critique of Theoretical Thought. The Collected Works of Herman Dooyeweerd, A-Series, Volumes A1-A4. General Editor D.F.M. Strauss. Lewsiston, NY : The Edwin Mellen Press.

EHLER, S. \& MORRALL, J.B. (Translators \& editors.) 1954. Church and State Through the Centuries. A Collection of Historic Documents with Commentaries. London : s.a.

FICHTER, J.H. 1968. Grundbegriffe der Soziologie. Edited by Erich Bodzenta. Berlin : Springer-Verlag.

GADAMER, H-G. 1998. Truth and Method. Second Revised Edition. New York : Continuum. 
GIDDENS, A. 1986. The Constitution of Society. San Diego : University of California Press.

GRIFFIOEN, S. 1986. De betekenis van Dooyeweerd's Ontwikkelingsidee. Philosophia Reformata, 51(1 \& 2):83-109.

GRONDIN, J. 1994. Introduction to Philosophical Hermeneutics. Yale Studies in Hermeneutics. Yale : Yale University Press.

HART, H. 1984. Understanding Our World, An Integral Ontology. Lanham : University Press of America.

HABERMAS, J. 1970. Erkenntnis und Interesse. Frankfurt am Main : Suhrkamp.

HABERMAS, J. 1996. Between Facts and Norms : Contributions to a Discourse Theory of Law and Democracy. Translated by William Rehg. 2nd print. Cambridge, Massachusettes : MIT.

HOLLINGER, R. 1994. Postmodernism and the Social Sciences. London : Sage.

KAMMLER, H. 1966. Der Ursprung des Staates. Eine Kritik der Ueberlagerungslehre. Köln : s.n.

KANT, I. 1956 [1781]. Kritik der reinen Vernunft. First edition. Hamburg : Felix Mainer.

KATES, P. 1928. The Two Swords. Washington : s.n.

KLAPWIJK, J. 1970. Tussen Historisme en Relativisme. Assen : Van Gorcum.

LEMAIRE, T. 1976. Over de waarde van kulturen. Baarn : Ambo.

LUHMANN, N., ed. 1985. Soziale Differenzierung: Zur Geschichte einer Idee. Opladem : West Jurbihe Verlag.

LUHMANN, N. 1990. The Paradox of System Differentiation and the Evolution of Society. (In Alexander, J.C. \& Colomy, P., eds. Differentiation Theory and Social Change, Comparitive and Historical Perspectives. New York : Columbia University Press.)

MANNHEIM, K. 1982. Structures of Thinking. Edited by David Kettler, Volker Meja and Nico Stehr and translated by Jeremy J. Shapiro and Shierry Weber Nicholson. London : Routledge \& Kegan Paul.

PORTMANN, A. 1969. Biologische Fragmente zu einer Lehre vom Menschen. 3rd expanded edition. Basel : Schwabe.

PRINSLOO, E.D. 1989. Logic and culture. South African Journal for Philosophy, 8(2):94-99.

STRAUSS, D.F.M. 1996. Rationalism, historicism and pan-'interpretationism'. (In Van der Meer, Jitse M. Facets of Faith and Science. Volume 2: The Role of Beliefs in Mathematics and the Natural Sciences. Pascal Centre : University Press of America. p. 99-122.)

STÜTTLER, J.A. 1969. Kirche und Staat. Pattloch : s.n.

VAN HUYSSTEEN, J.W.V. 1998. Duet or Duel? Theology and Science in a Postmodern World. Harrisburg, Pennsylvania : Trinity Press International.

VAN HUYSSTEEN, J.W.V. 1999. The Shaping of Rationality. Toward Interdisciplinarity in Theology and Science. Grand Rapids : Eerdmans.

VAN RIESSEN, H. s.a. Nietzsche. De Radicale Humanist. (In Zuidema, S.U. Denkers van deze Tijd, Volume I. Francker : Wever. p. 65-107.)

VON SAVIGNY, F.C. 1948. Grundlagen der historischen Rechtschule. Frankfurt am Main : Klostermann. 


\section{Key concepts:}

individuality and changefulness/universality and constancy late scholastic nominalism normativity undifferentiated societies or cultures/differentiation \& integration

\section{Kernbegrippe:}

individualiteit en veranderlikheid/universaliteit en konstansie laat-skolastiese nominalisme normatiwiteit ongedifferensieerde samelewings en kulture/differensiasie \& integrasie 